\title{
Squamous-cell carcinoma arising in a pilonidal sinus: case report and review of the literature
}

\author{
Antonio Martino ${ }^{1}$, Ciro De Martino ${ }^{2 *}$, Anna Pisapia², Gautam Maharajan ${ }^{1}$, Marco Evangelista $^{1}$ \\ From XXIII Annual Meeting of the Italian Society of Geriatric Surgery \\ Lecce, Italy. 2-4 December 2010
}

\section{Background}

Squamous-cell carcinoma arising in a pilonidal sinus is a rare complication of a common disease. More than 60 cases are reported in literature. In all patients, squamous carcinoma arises in a long-term pilonidal disease. The gold-standard for treatment is radical excision of the neoplasm, with tumour-free margins. Some Authors consider the effectiveness of postoperative chemo- or radiotherapy, to reduce local recurrence.

\section{Methods}

Authors report the case of a 65-years old male, with a 15 -year history of recurrent pilonidal disease. He was admitted to the General Surgery Unit because of the development of a bleeding ulcerated lesion in the pilonidal area. The patient underwent an incisional biopsy (showing squamous-cell carcinoma), preoperative staging with total body CT-scan, and finally radical surgery. The large wound healed by secondary intention. Definitive histology confirmed diagnosis and revealed tumourfree margins. After being discharged, the patient was followed up on as an outpatient.

\section{Results}

Hospital stay took 10 days, due to the complexity of the first medications. A posterior rectocele was observed, but no functional diseases were identified. The complete formation of the scar took three months. After six months, no complication or signs of recurrence were observed.

\section{Conclusions}

Squamous-cell carcinoma arising in a pilonidal sinus is a rare occurrence that develops only in long-standing pilonidal diseases. The tumour grows very slowly, but has a high local invasivity. Inguinal lymphadenopaties at the time of diagnosis is related to a poor prognosis. Local recurrence is usual and early. Enlargement of excision in case of local recurrence, and abdomino-perineal resection if sphincters are involved, may improve survival rates. There are not enough trials to assess the usefulness of preoperative or postoperative chemo- and radio- therapy.

\section{Author details}

${ }^{1}$ Casa di Cura "A. Grimaldi" di San Giorgio a Cremano (NA). Dipartimento di Chirurgia, Italy. ${ }^{2}$ Università degli Studi di Napoli "Federico II". U.O.C. di

Chirurgia Generale, Italy.

Published: 24 August 2011

\section{References}

1. Abboud $B$, Ingea $H$ : Recurrent squomous-cell carcinoma arigins in sacrococcygeale pylonidal sinus tract. Dis Colon Rectum 1999, 4:525-28

2. Chatzis I, Noussios G, Katsourakis A, Chatzitheoklitos E: Squamous cell carcinoma related to long standing pilonidal-disease. Eur J Dermatol 2009, 19(4):409-9.

3. Kulaylat MN, Gong M, Doerr RJ: Multimodality treatment of squamous cell carcinoma complicating pilonidal disease. Am Surg 1996, 62(11):922-9.

doi:10.1186/1471-2318-11-S1-A28

Cite this article as: Martino et al: Squamous-cell carcinoma arising in a pilonidal sinus: case report and review of the literature. BMC Geriatrics 2011 11(Suppl 1):A28.

\footnotetext{
* Correspondence: ciro.de@tiscali.it

¿Università degli Studi di Napoli "Federico II". U.O.C. di Chirurgia Generale, Italy

Full list of author information is available at the end of the article
} 